\title{
When physical oceanography meets population genetics: The case study of the genetic/evolutionary discontinuity in the endangered goliath grouper (Epinephelus itajara, Perciformes: Epinephelidae) with comments on the conservation of the species
}

\author{
Benevides E. A. ${ }^{1}$, Vallinoto M. N. S. ${ }^{2}$, Fetter Filho A. F. H. ${ }^{3}$, De Souza J. R. B. ${ }^{4}$, Silva-Oliveira G. ${ }^{2}$ \\ Freitas M. O. ${ }^{5}$, Ferreira B. P. ${ }^{6}$, Hostim-Silva M. ${ }^{7}$, Bertoncini A. A. ${ }^{8}$, Blanchard Fabian ${ }^{9}$, Torres R. A. ${ }^{1,}$ * \\ ${ }^{1}$ Univ Fed Pernambuco, Ctr Ciencias Biol, Dept Zool, Lab Genom Evolut \& Ambiental, BR-50670420 \\ Recife, PE, Brazil \\ ${ }^{2}$ Fed Univ Para, Inst Estudos Costeiros, Lab Genet \& Biol Mol, Braganca, Para, Brazil . \\ ${ }^{3}$ Univ Fed Santa Catarina, Ctr Filosofia \& Ciencias Humanas, Dept Geociencias, Florianopolis, SP, \\ Brazil. \\ ${ }^{4}$ Univ Fed Pernambuco, Ctr Ciencias Biol, Dept Zool, Recife, PE, Brazil . \\ ${ }^{5}$ Univ Fed Parana, Programa Posgrad Ecol \& Conservacao, Niteroi, RJ, Brazil . \\ ${ }^{6}$ Univ Fed Pernambuco, Dept Oceanog, Niteroi, RJ, Brazil \\ ${ }^{7}$ Univ Fed Espirito Santo, CEUNES, Dept Ciencias Agr \& Biol, Niteroi, RJ, Brazil. \\ ${ }^{8}$ Univ Fed Estado Rio de Janeiro, Programa Posgrad Biodiversidade Neotrop, CCET, IBIO, BR- \\ 22290240 Rio de Janeiro, RJ, Brazil. \\ ${ }^{9}$ IFREMER, Palavas Les Flots, France.
}

Corresponding author : R.A. Torres, Tel.: +55 8199715401, +55 8196929547.; email

address : rodrigotorres@ufpe.br

benevides ea@hotmail.com

\begin{abstract}
:
Epinephelus itajara is one of the marine fish species most threatened for extinction and it is considered to be "critically endangered" by the IUCN. The present study evaluated the genetic diversity of the species and the genetic/evolutionary relationships of its populations along the Atlantic coast of South America. The results indicate relatively reduced genetic variation, re-emphasizing the low adaptive potential of the species. One of the populations presented relatively high degrees of genetic diversity and it is evolutionary isolated from the all other populations. The evidences indicate the existence of two Evolutionarily Significant Units comprising E. itajara in the Atlantic coast of South America and the conservation prospects for the species must take these evidences into account.
\end{abstract}




\section{Highlights}

- A low genetic diversity was confirmed in Epinephelus itajara. The species is divided into two genetic/evolutionary lineages. A possible ESU of E. itajara occurs at the Babitonga bay (Southern Brazil). Physical oceanography explains the isolation at the Babitonga bay (Southern Brazil). Also a panmictic population occurs in the rest of the Atlantic coast of South America.

Keywords : Epinephelus itajara, ISSRs, Population genetics, Conservation genetics

\section{Abbreviations}

- IBAMA, Brazilian Federal Environment Institute;

- IUCN, International Union for Conservation of Nature;

- FG, French Guiana;

- PA, Pará;

- PI, Piauí;

- CE, Ceará;

- RN, Rio Grande do Norte;

- PE, Pernambuco;

- BA, Bahia;

- SP, Sao Paulo;

- PR, Paraná;

- SC, Santa Catarina

\section{Introduction}

One of the most interesting challenges in evolutionary biology is the identification of the processes responsible for the genetic variability of closely-related or geographically distant populations (Pampoulie et al., 2004). In this context, gene flow is one of the principal processes affecting the evolutionary history of species and their genetic structuring (Hauser and Carvalho, 2008), because it determines the extent to which each population can be considered an independent evolutionary unit (Slatkin, 1993).

In marine environments, gene flow among most fish species is facilitated by the dispersal of larvae on oceanic currents (Cowen et al., 2006 and Cowen et al., 2007). As most marine environments appear to be homogeneous, relatively low rates of evolutionary change 
might be expected in these fish populations (Hauser and Carvalho, 2008). However, a number of studies have found evidence of genetic structuring among populations of marine fishes related to environmental gradients (Lecomte et al., 2004; Gonzalez and Zardoya, 2007), oceanographic barriers to dispersal and uneven distribution of habitats (Lessios and Robertson, 2006; Patarnello et al., 2007; Galarza et al., 2009), in addition to local genetic adaptations (Williams and Oleksiak, 2008).

Given these considerations, studies of gene flow and variability constitute a useful tool for the investigation of the connectivity among populations, providing important insights into the demographic history of the populations and the selection pressures that have molded genetic variation, as well as the mutational processes that generate diversity (Freeland, 2005; Conrad and Hurles, 2007). A detailed understanding of all these processes is crucial to the development of conservation strategies, in particular for over-exploited and/or endangered fish species, in which harvesting pressures and the destruction of habitats essential to specific phases of the life cycle, may lead to the genetic isolation of populations (Craig, 2011).

Epinephelus itajara (Lichenstein 1822) is the largest grouper found in the Atlantic Ocean, including western Africa and the tropical and subtropical regions of the New World (Craig et al., 2011). In the Americas, the species is found in shallow and coastal waters between eastern Florida and southern Brazil, including the Gulf of Mexico and the Caribbean (Smith, 1971; Heemstra and Randall, 1993; Craig et al., 2009). It is a long-lived species, able to survive for more than 37 years, which reaches sexual maturity at 5 to 8 years of age, and may grow to $2.5 \mathrm{~m}$ in length, with a weight of up to $455 \mathrm{~kg}$ (Robins et al., 1986; Bullock et al., 1992). During the breeding season spawning aggregations are formed, which facilitate the harvesting of the species by fishermen (Coleman and Williams, 2002; Gerhardinger et al., 2009). 
These biological and ecological characteristics of the species, combined with overfishing and the ongoing destruction of estuarine habitats, which are essential to the initial stages of its life cycle (Bullock et al., 1992; Frias-Torres, 2006), have resulted in the goliath grouper being considered to be one of the marine fish species most threatened with extinction anywhere in the World (Craig, 2011). The species is listed by the IUCN as critically endangered, and in 2002, specific legislation (ordinance 121) was issued by the Brazilian Federal Environment Institute (IBAMA) prohibiting the capture, fishing or sale of goliath groupers anywhere in Brazilian coast. During this period of protection, it is essential to guarantee the continuous evaluation of the conservation status of the species, and to define the areas appropriate for the management of remaining populations.

Genetic studies of E. itajara have indicated the effectiveness of molecular markers for the interpretation of the history of populations, and their genetic connectivity and conservation status. Analyzing the mitochondrial genome, Craig et al. (2009) confirmed the presence of cryptic species in the Atlantic and Pacific oceans, as well as a genetic connection between populations from Brazil and Belize, despite the distance of more than $1,000 \mathrm{~km}$ that separates the two populations. Such study also stated the resurrection of the supposedly extinct species Epinephelus quiquefasciatus in the tropical Pacific Ocean. Silva-Oliveira et al. (2008) and Seyoum et al. (2013) found relatively reduced genetic variability respectively in the control region (mtDNA) and at the microsatellite loci of E. itajara, even being the genome regions with high rates of differentiation. In addition much more of the genealogical history of the species, these studies have confirmed vulnerability of the species to ongoing anthropogenic impacts. However, up until now, no innovator molecular studies in the species have focused on nuclear markers, such as the ISSRs (Inter Simple Sequence Repeats). The analysis of markers 
derived from distinct genome regions might provide important complementary insights into the genetic diversity of the species and its vulnerability to extinction.

ISSR markers are extensively used in plants and they have been also used in studies on the evolutionary history at population and species levels in a wide variety of aquatic species especially in fishes (Yang et al., 2011; Kumla et al., 2012; Li et al., 2013).

Given these considerations on the genetic and ecological characteristics of the species, the present study tested the previous hypotheses on the genetic variation of the $E$. itajara populations from the Atlantic coast of South America, based on those nDNA markers. This approach provides the basis for a better understanding of the genetic diversity of the species (potential adaptation), the identification of possible population structuring, and the expansion of the database on the genealogical history of the species within its geographic range. The data presented in this study will contribute for the planning of effective strategies for the management of E. itajara populations, considering that the preservation of genetic variability and the processes underlying this variability will be crucial to the conservation of the species over the long term (Moritz, 2002).

\section{Materials and methods}

\subsection{Sampling, DNA extraction, and PCR protocol}

Samples of tissue from the liver, fins or muscles were obtained from 95 specimens of $E$. itajara collected at 10 sites in South America, including French Guiana (FG) and Brazil (Table 1 and Fig. 1). In Brazil, the localities were Ajuruteua Beach in the state of Pará (PA), the estuary of the Parnaíba River in Piauí (PI), the coast of Ceará (CE), the estuary of the Potengi River in Rio Grande do Norte (RN), the estuary of the Formoso 
River in Pernambuco (PE), Caravelas river and Abrolhos adjacent shelf in Bahia (BA), São Vicente in São Paulo (SP), the coast of Paraná (PR), and São Francisco do Sul in Santa Catarina (SC).

The DNA was extracted using the DNeasy extraction kit (QIAGEN) and a modified phenol-chloroform protocol based on the method described by Sambrook and Russel (2001). The integrity of the DNA was checked by electrophoresis in agarose gels and the concentration estimated by visual comparison with the intensity of the DNA of the Lambda phage. The DNA was then diluted to a standard concentration of $5 \mathrm{ng} / \mu \mathrm{L}$ for the PCR-ISSR reactions.

Seventeen di- or trinucleotides ISSR primers were tested for their reproducibility and polymorphisms in different days with different brands of PCR reagents (Table 2). Eight of those primers were selected based on generating a minimum of 60 polymorphic loci, as recommended by Telles et al. (2001) and Nelson and Anderson (2013).

The PCR reactions followed the procedures suggested by Almeida et al. (2003). Each PCR reactions solution consisted of $1 \mathrm{U}$ of Taq DNA Polymerase (New England Biolabs), $2 \mu \mathrm{L}$ of buffer solution $(10 \mathrm{x}), 0.5 \mu \mathrm{L}$ of $\mathrm{MgSO}_{4}(20 \mathrm{mM}), 0.5 \mu \mathrm{L}$ of each ISSR primer $(50 \mu \mathrm{M}), 1.5 \mu \mathrm{L}$ of dNTP $(1.5 \mathrm{mM})$, and $5 \mathrm{ng}$ of DNA in a total volume of $20 \mu 1$. The PCRs were conducted in the Biocycler thermocycler and consisted of one cycle of 4 minutes at $94{ }^{\circ} \mathrm{C}$, followed by 39 cycles of $40 \mathrm{~s}$ at $94^{\circ} \mathrm{C}, 40 \mathrm{~s}$ at the specific temperature to each primer (Table 2), and $2 \mathrm{~min}$ at $72^{\circ} \mathrm{C}$, with final extension of $7 \mathrm{~min}$. The PCR results were revealed by horizontal electrophoresis in $1.8 \%$ agarose gels, containing TBE buffer $(0.5 \mathrm{x})$, for 4 hours at 60 volts. The band sizes were estimated by comparisons with $1 \mathrm{~Kb}$ DNA ladder (Fermentas).

\subsection{Data analysis}


The genetic polymorphisms were transformed in a binary $(0 / 1)$ matrix, in which the specimens were genotyped based on the presence (1) or absence (0) of bands at specific molecular weights. In order to avoid the use of supposed markers (small smears and weak bands) at one or another sample, only clear and well-defined bands were assigned as markers. The genetic diversity of E. itajara was estimated by the proportion of polymorphic loci for both the global set of loci and in relation to the global set of loci recorded at each location (population), considering the total number of polymorphic loci as $100 \%$. The localities represented by fewer than five specimens were not included in the analyses of genetic diversity and population genetics, due to their reduced sample size. The average genetic diversity of each population was also measured by simple arithmetic mean calculations at both: diversity the global set of loci and in relation to the global set of loci recorded at each location.

Population genetic parameters were obtained by using Popgene version 1.3.2 (Yeh et al., 1999) to calculate the Neies gene diversity (h), Shannon's information index (Is), total genetic diversity $(\mathrm{Ht})$, genetic diversity within populations (Hs), inter-specific genetic differentiation $\left(\mathrm{G}_{\mathrm{ST}}\right)$ and the gene flow $\left(\mathrm{N}_{\mathrm{m}}=\right.$ Number of migrants per generation). They were also estimated for both global data and pairwise populations (SC and the other populations).

An Analysis of Molecular Variance (AMOVA) was used to test possible deviations from a uniform genetic structure across populations (Excoffier et al., 1992) by using Arlequin 3.5.1.2 (Excoffier and Lischer, 2010) and a total of three fixation indices were also calculated [the intraspecific index of fixation of genetic variance $\left(\Phi_{\mathrm{ST}}\right)$, and the indices for fixation between groups $\left(\Phi_{\mathrm{CT}}\right)$ and within groups $\left.\left(\Phi_{\mathrm{SC}}\right)\right]$. For this analysis, the populations were grouped into three ways: (a) with all samples together, (b) with two main groups: SC one group and the remaining samples another group, and (c) 
without the samples with just one and two specimens accessed (Ceará, São Paulo, and Paraná).

In order to evaluate possible genetic/evolutionary groupings, Multi Dimensional Scaling (MDS) by Simple Matching technique (Primer software) and Maximum Parsimony (MP - Fitch, 1971) methods were used. This last was developed by using PAUP v.4.0b10* program (Swofford, 2000), by its graphic interface PaupUp v.1.0.3.1 (Calendini and Martin, 2005) with Epinephelus morio and Mycteroperca marginata as outgroups. MP analysis was performed through heuristic searches, with the characters designated as „,not-ordered ${ }^{\text {eee }}$ and with equal weights. The MaxTrees number of trees analyzed was 100,000 with 5000 random replications by random addition of terminals and the treebisection-reconnection (TBR) algorithm for branch swapping. The strict consensus tree was computed and the robustness of the resulting topology was assessed through bootstrap and jackknife analyses with 1000 pseudo replicates as well as through heuristic searches using the fast stepwise addition of terminals and TBR for branch swapping.

A matrix of average genetic distances was produced by the Neighbor-Joining analysis from the pairwise distances between specimens analyzed. These genetic distances were compared with the geographic distances (in kilometers; Google Earth platform) between localities using a linear regression analysis (Statistica v.6.0; Statsoft Inc.). This approach was used to verify the possible isolation by distance (IBD) phenomena among the different populations.

Population structurings were tested using the Bayesian approach by using the Structure 2.3.3 software (Pritchard et al., 2000; Falush et al., 2003; 2007; Hubisz et al., 2009). In order to determine the number of populations $(\mathrm{K})$ within the complete data set, ten independent simulations for $\mathrm{K}=1-10$ with 100,000 burnin interactions were computed. 
The analysis was performed by using both the admixture model of population structure and allele frequencies correlated among populations. The number of populations $(\mathrm{K})$ was estimated using the protocol described by (Evanno et al., 2005)

\section{Results}

\subsection{Genetic diversity and population genetics}

The eight ISSR primers used resulted in a total of 94 loci. The PCR products varied in length from 250 to 1700 base pairs (bps) as exemplified in the Fig. 2. Overall, 92 of the total loci were polymorphic, while two were monomorphic, indicating a global polymorphism (genetic diversity) of $97.8 \%$ for E. itajara within the study area.

The polymorphism observed within each locality as a proportion of total diversity was higher in SC for both rather than in the other populations (79.8\% -Table 3), and than at each locality in relation to the set of loci present at each locality (94.9\% - Table 4). The obtained values of the genetic diversity are showed in the Tables V and VI. Neiees gene diversity $(h)$ and Shanon 's information index (I) were highest in the SC population $(h=0.1457 / \mathrm{I}=0.2273)$ rather than in the other populations accessed $(h=0.1314 / \mathrm{I}=0.1996)$ (Table 5). The total genetic diversity (Ht) observed was 0.2119 , while the genetic diversity within populations (Hs) was 0.1385 . The global $\mathrm{G}_{\mathrm{ST}}$ and $\mathrm{Nm}$ were 0.3463 and 0.95/generation respectively (Table 6). The pairwise data are shown in the Table 7.

AMOVA indicated that $57.2 \%$ of the total variation is found within the populations analyzed, and $42.7 \%$ among populations, with a global $\Phi_{\mathrm{ST}}$ index of 0.427 (Table 8). A second AMOVA was also carried out in order test for the two groups indicated by the topology of the grouping analyses, with group 1 being formed by FG, PA, PI, CE, RN, 
PE, BA, SP, and PR, and group 2 by SC (Table 9). In this analysis, the genetic variance between groups was $43.6 \%$, while that between populations within groups was $18.1 \%$, and that within groups was $38.1 \%$. This analysis also indicated the fixation indices of $\Phi_{\mathrm{CT}}=0.436, \Phi_{\mathrm{SC}}=0.322$, and $\Phi_{\mathrm{ST}}=0.618$. The AMOVA without those aforementioned samples (please read in the M\&M section) indicated no significant different values by comparing with the first and second analyzes carried out.

\subsection{Grouping analyses}

The simple matching MDS analyses also revealed two major groups at both populations and regional scales (stress 0.07 ). In summary the analysis indicated the existence of two major groups: (a) SC population and (b) the remaining sampled populations (Fig. 3(a, b)).

The MP analysis generated a total of 25,000 equally-parsimonious trees (Length $[$ number of steps $]=643$, Consistency index $[\mathrm{Ci}]=24$, and Retention index $[\mathrm{Ri}]=71$ ). The consensus tree (strict consensus) generated a topology with Length $(\mathrm{L})=685, \mathrm{Ci}=$ 33, and $\mathrm{Ri}=69$. This topology (Fig. 4) recovered the previous groupings as two monophyletic groups well-supported by both bootstrap and jackknife values. One clade grouped the most of the specimens from Santa Catarina (SC), and the other by the remaining specimens from the other localities, as well as a few from SC. In addition no evidence was found regarding for co-relationship among genetic and geographic distances $\left(\mathrm{R}^{2}=0.034, \mathrm{p}>0.05\right)$ (Fig. 5). The results of the Bayesian analysis for population structuring indicated the existence of $\mathrm{K}=2$ genetic-evolutionary populations (Fig. 6) with a genetic profile representing the SC population and one another representing the remaining populations. 


\section{Discussion}

\subsection{Genetic diversity and conservation status}

Despite the overall polymorphism of Epinephelus itajara had been very high $(97.8 \%)$ the diversity observed within each location was lower ( $48.8 \%$ - Table 3 and 4$)$, except for the sample from Santa Catarina (SC; 94\%). These findings seem to do not reflect a large variation within the species given the Shannon's and Neies index of diversity showed low values (Table 5 and 6). Analyses of genetic diversity in this species have indicated low levels of variation, even in the genome regions with high rates of nucleotide variation (e.g., mitochondrial Control Region - Silva-Oliveira et al., 2008; microsatellite loci - Seyoum et al., 2013). The overexploited and endangered Epinephelus bruneus shows also its average genetic variation in around $46 \%$ and the mean observed and expected heterozygosities of 0.47 and 0.61 respectively in the nuclear genome (microsatellite loci) (An et al., 2012). These findings indicate that the overall diversity observed in the study did not reflect the mean moderate to low genetic diversity (potential adaptation) observed in the species. While genetic variation is the raw material for adaptation and thus, the persistence of the species, the results of the present study reinforced that E. itajara populations from the western Atlantic might be considered as vulnerable to environmental change and/or fishing exploitation. Therefore the data obtained herein do reinforce the status of the species as critically endangered by IUCN (2010).

The genetic diversity and the genetic profiles observed in the sample from Santa Catarina (SC) were very distinct by comparing with other accessed populations. In addition the values from $\mathrm{G}_{\mathrm{ST}}$ and $\mathrm{Nm}$ indicated that populations from $\mathrm{SC}$ were highly differentiated from the others $\left(\mathrm{G}_{\mathrm{ST}} \geq 0.25\right.$ and $\left.\mathrm{Nm}<1\right)$. It seems likely that much of the 
diversity observed in this sample is related to a possible historical process of genetic isolation, leading to a random fixation of distinct genetic variants.

The data provided in the most recent IUCN diagnosis on the conservation status of $E$. itajara showed a declining demographic situation (Craig, 2011). Such situation is more pronounced in the Southeastern and Southern Brazil in which underwater fishing at spawning aggregation season is one of the main causes regarding the species declining (Gerhardinger et al., 2009). Therefore it seems that the differentiation of the SC population might be the result of isolation and genetic drift regimes in a small population of E. itajara in that region. A similar pattern of high genetic diversity was detected at the exploited and endangered E. marginatus (sensu Mycteroperca marginata) (Schunter et al., 2011). Thus, the joint evidences indicate how important are the genetic data in order to diagnose the levels of genetic variation as well as its spatial distribution along the geographical range of an endangered species. In addition such data allow rationale management and conservation plannings focusing the recovering of endangered fish species as Epinephelus itajara.

Considerable variation was observed in the percentage of polymorphic loci in different populations (Tables 3 and 4), with the lowest values being recorded in northeastern Brazil, i.e. PI (36.8\% and $24.5 \%)$ and RN (32.9\% and 26.6\%). These values indicated the highest risk of extinction of E. itajara at these localities. Yet the variation observed suggests these populations as having high priority for genetic rescue strategies in Southern Atlantic as already applied for some other endangered species (Johnson et al., 2010; Wikramanayake et al., 2011).

\subsection{Population connectivity, evolution, and conservation}


As aforementioned, the MDS analysis revealed the existence of two distinct genetic units for E. itajara, with strong support (stress 0.07). The existence of these two units indicates the loss of connectivity between these populations and such phenomenon seems to be not correlated with the IBD model. On contrary new reef fish assembling in the Santa Catarina coast supported the hypothesis of a narrow connectivity by larval movements throughout the mentioned regions. Such movements would be favored by the Brazilian Current (Barneche et al., 2009). Epinephelus itajara would be an additional example reinforcing such pattern given their larvae are planktonic (Sadovy and Eklund, 1999), favoring the connectivity. The narrow genetic relationships among the more distant populations observed within the second unit reinforced that global dispersal pattern, indicating the presence of an ample and panmitic population of $E$. itajara throughout the rest of the Atlantic coast of South America. A similar situation was also observed by the mitochondrial genome of E. itajara (Craig et al., 2009; Torres et al., in prep.).

However the data obtained herein failed to support such pattern of connectivity and also arguments in favor to a strong genetic division. Such phenomenon indicates a new perspective on the population connectivity among locations from the Brazilian coast and requires case-by-case genetic connectivity studies in order to confirm the general patterns of population connectivity as proposed by Barneche et al. (2009).

Two hypotheses may be proposed in order to explain such separation: the SC population is exclusive of the Babitonga Bay area or, this latitude represents a geographic frontier and this population is observed elsewhere south of the latitude of the Babitonga Bay. Unfortunately, the lack of data south of the Babitonga Bay does not allow us to disregard any of these hypotheses. 
The hydrologic and oceanographic characteristics of the Babitonga Bay depict a semienclosed environment with weak exchange with the continental shelf: low fluvial discharge $\left(\sim 20 \mathrm{~m}^{3} \cdot \mathrm{s}^{-1}\right.$, Nacional Water Agency, www.ana.gov.br) and large shallow mangrove areas that favor precipitation and retention of larvae (Mazzer and Gonçalves, 2011; Oliveira, 2006). The Babitonga Bay is the most important estuary of Santa Catarina State, the mangrove area is approximately 6,200 ha (IBAMA, 1998), and sand beaches and rocky margins form its margins. These are characteristics that support the hypothesis of a population exclusive to the Babitonga Bay given it seems to be a closed system.

However, the second hypothesis that the surrounds of the latitude of the Babitonga Bay represent a geographic boundary for the population of $E$. itajara that is found in the Bay is also a plausible one. The Plata Plume Water is observed along the coast of Uruguay, Rio Grande do Sul State (Brazil) and Santa Catarina State (Brazil). This relatively cold tongue of water is present over the continental shelf throughout the year. However, its northern most extent is modulated by the surface wind stress acting on the oceanatmosphere interface (Moller $\mathrm{Jr}$ et al., 2008). During the summer, the prevailing northeastern winds push the Plata Plume Water towards south, usually during this time of the year this boundary is found over the continental shelf of Rio Grande do Sul. During the winter, the prevailing winds are from south, pushing Plata Plume Water towards north (Fig. 7). This peculiar temperate pattern may favor the establishment of one population over another. Moreover, the spawning aggregations of the E. itajara have been reported to occur during early summer (December), therefore, if any larvae manage to find its way out to the continental shelf, it will likely face northeastern winds that would push the larvae towards south. The northeastern winds would act as a barrier to the displacement of the larvae towards north. Also, December is a month of moderate 
river discharge, favoring larvae retention in the shallow mangrove areas of the Babitonga Bay.

Despite the lack of clear evidences regarding coastal current dynamics along the coast of South America affecting the populations of E. itajara, studies with E. marginatus (sensu Mycteroperca marginata) suggested the role of ocean currents shaping the genetic structure in the species by promoting specific local larval retention (Schunter et al., 2011). In the present case, the separation of the SC population might be related to the dynamics of marine coastal currents along the coast of South America or possibly to a behavior of local fidelity. However additional oceanographic studies are necessary in the region in order to confirm the dynamics of those coastal currents especially in the water circulation into the Babitonga bay (sampling location of the SC population). As argued a weak water circulation towards to open sea could reduce drastically larvae movements throughout the Brazilian coast favoring phylopatry in the region.

The maximum parsimony analysis indicated the existence of two monophyletic groups of E. itajara within the study area, consistent with the distinct genetic units observed MDS analysis. While the evidence presented herein indicates a degree of evolutionary cohesion in E. itajara within the study area, it also highlights the discontinuity in the Santa Catarina coast. Overall, the species seems to present a historical tendency for genetic structuring, which is reinforced by the results from AMOVA and the F statistics $\left(\Phi_{\mathrm{SC}}, \Phi_{\mathrm{ST}}\right.$, and $\Phi_{\mathrm{CT}}$ - values above 0.25 - Hartl and Clark, 2010; Wright, 1951).

The division of the global sampling into two well-defined monophyletic groups is further supported by the Bayesian analysis, which supported the existence of two genetically-differentiated evolutionary units. In this case, the evidence is possibly consistent with the existence of two Evolutionary Significant Unit (ESU) comprising $E$. itajara along with its geographical range. 
In summary E. itajara presented only a moderate level of global genetic variation $(\sim 50 \%)$, confirming the species as vulnerable to extinction. The local populations from Parnaíba (PI) and Potengi (RN) rivers are truly priorities to conserve E. itajara in the regions given their low genetic diversity. However, the population from Santa Catarina (SC) presented relatively high levels of genetic diversity and distinctiveness. Otherwise it arguments in favor to an alternative hypothesis such as the putative low water circulation within Babitonga bay towards to the open sea favoring larvae retention around the region.

The results of the present study indicate the need to manage distinctly the E. itajara ESUs in order to maintain their genetic and evolutionary integrity. In addition, the configuration of the genetic diversity and evolutionary history of these ESUs must also be taken into account during any attempt at genetic restoration (increase in adaptive potential).

Additionally Babitonga Bay has been considered a region for a conservation reserve given several biotic and abiotic features characterizing the region (ICMBio, 2011). The genetic differentiation of E. itajara from Babitonga Bay argument in favor to reinforce the implementation of a conservation reserve given its singularity in the region.

\section{Acknowledgments}

The authors are grateful to the Conservation Leadership Programme and Conservation International Brazil - Marine program for the support. We are also grateful to the team of the Meros do Brasil Project maintained by "Programa Petrobrás Ambiental" for supplying the tissue samples. We thank to FACEPE (Fundação de Amparo à Pesquisa e Tecnologia do Estado de Pernambuco), CNPq (Conselho Nacional de Desenvolvimento 
Científico e Tecnológico - Edital Universal and the Research Fellowship to RATorres Proc. number 307248/2008-9), and UFPE (Universidade Federal de Pernambuco) for financial support.

\section{References}

An, H. S., Kim, J. W., Lee, J. W., Kim, S. K., Lee, B. I., et al. (2012). Development and characterization of microsatellite markers for an endangered species, Epinephelus bruneus, to establish a conservation program. Anim Cell Syst, 16, 50-56.

Almeida, F. S., Sodré, L. M. K. \& Contel, E. P. B (2003). Population structure analysis of Pimelodus maculatus (Pisces, Siluriformes) from the Tiete and Paranapanema River (Brazil). Genet Mol Biol, 26, 301-305.

Barneche, D. R., Anderson, A. B., Floeter, S. R., Silveira, M., Dinslaken, D. F. \& Carvalho-Filho, A. (2009). Ten new records of reef fish on the coast of Santa Catarina State, Brazil. Mar Biodivers Records, 2, 1-4.

Bullock, L. H., Murphy, M. D., Godcharles, M. F. \& Mitchell, M. E. (1992). Age, growth, and reproduction of jewfish Epinephelus itajara in the eastern Gulf of Mexico. Fish Bull, 90, 243-249.

Calendini, F. \& Martin, J.F. (2005). PaupUp v1.0.2032.22590 Beta. A free graphical frontend for Paup* Dos software.

Coleman, F. C. \& Williams, S. L. (2002). Overexploiting marine ecosystem engineers: potential consequences for biodiversity. Tren Ecol Evol, 17, 40-44.

Conrad, D. F. \& Hurles, M. E. (2007). The population genetics of structural variation. Nature Genet Suppt, 39, S30-S36. doi:10.1038/ng2042 
Cowen, R. K., Paris, C. B. \& Srinivasan, A. (2006). Scaling of Connectivity in Marine Populations. Science, 311, 522-527.

Cowen, R. K., Gawarkiewicz, G., Pineda, J., Thorrold, S. R. \& Werner, F. E. (2007). Population connectivity in marine systems. Oceanography, 20, 14-21.

Craig, M. T., Graham, R. T., Torres, R. A., Hyde, J. R., Freitas, M. O., et al. (2009). How many species of goliath grouper are there? Cryptic genetic divergence in a threatened marine fish and the resurrection of a geopolitical species. Endang Species Res, 7, 167-174. doi: 10.3354/esr00117

Craig, M. T. (2011). IUCN Red List of Threatened Species. Version 2012.1. Available at http://www.iucnredlist.org/ (last accessed 13 July 2012).

Craig, M. T., Sadovy de Mitcheson, Y. J. \& Heemstra, P. C. (2011). Groupers of the World: A field and Market Guide. NISC/IUCN. 356p.

Oliveira, F. A. (2006). Estudo do aporte sedimentar em suspensão na Baía da Babitonga sob a ótica da geomorfologia. Doctoral Thesis. Universidade de São Paulo, São Paulo, Brazil.

Excoffier, L., Smouse, P. E. \& Quattro, J. M. (1992). Analysis of molecular variance inferred from metric distances among DNA haplotypes application to human mitochondrial-DNA restriction data. Genetics, 131, 479-491.

Excoffier, L. \& Lischer, H. E. L. (2010). Arlequin suite ver 3.5: A new series of programs to perform population genetics analyses under Linux and Windows. Mol Ecol Res, 10, 564-567

Evanno, G., Regnaut, S. \& Goudet, J. (2005). Detecting the number of clusters of individuals using the software STRUCTURE: a simulation study. Mol Ecol, 14, $2611-2620$ 
Falush, D., Stephens, M. \& Pritchard, J. K. (2003). Inference of population structure: extensions to linked loci and correlated allele frequencies. Genet, 164, 1567-1587

Fitch, W. M. (1971). Towards defining the course of evolution: minimum change for a specific tree topology. Syst Zoo, 20, 406-416.

Freeland, J. R. (2005). Molecular Ecology. John Wiley \& Sons Ltd, West Sussex.

Frias-Torres, S. (2006). Habitat use of juvenile goliath grouper Epinephelus itajara in the Florida Keys, USA. Endang Species Res, 2, 1-6.

Galarza, J. A., Carreras-Carbonell J., Macpherson, E. Pascual, M., Roques, S., et al. (2009). The influence of oceanographic fronts and early-life-history traits on connectivity among littoral fish species. Proc Natl Acad Sci USA, 106, 1473-1478. doi:10.1073/pnas.0806804106

Gerhardinger, L. C., Hostim-Silva, M., Medeiros, R. P., Matarezi, J., Bertoncini, A. A., et al. (2009). Fishers' resource mapping and goliath grouper Epinephelus itajara (Serranidae) conservation in Brazil. Neotrop Ichthyol, 7, 93-102.

Gonzalez, E. \& Zardoya, R. (2007). Relative role of life-history traits and historical factors in shaping genetic population structure of sardines (Sardina pilchardus). BMC Evol Biol, 7, 197. doi:10.1186/1471-2148-7-197

Hartl, D. L. \& Clark, A. G. (2010). Princípios de Genética de Populações. 4. Ed. ArtMed. Porto Alegre-RS, Brazil.

Hauser, L. \& Carvalho, G. (2008). Paradigm shifts in marine fisheries genetics: ugly hypotheses slain by beautiful facts. Fish Fish, 9, 333-362.

Heemstra, P. C. \& Randall, J. E. (1993). FAO species catalogue. vol. 16. Groupers of the world (Family Serranidae, Subfamily Epinephelinae). An annotated and illustrated catalogue of the grouper, rockcod, hind, coral grouper and lyretail species known to date. FAO Fisheries Synopsis no. 125, FAO. Rome. 
Hubisz, M. J., Falush, D., Stephens, M. \& Pritchard, J. K. (2009). Inferring weak population structure with the assistance of sample group information. Mol Ecol Res, 9, 1322-1332. doi: 10.1111/j.1755-0998.2009.02591.x

ICMBio. (2011). Plano de ação nacional para a conservação dos mamíferos aquáticos pequenos cetáceos. 132pp.

Instituto Brasileiro do Meio Ambiente e dos Recursos Naturais Renováveis (IBAMA). (1998). Manguezal da Baía da Babitonga. Coleção Meio Ambiente. Série Estudos Pesca, 25. Itajaí: IBAMA / CEPSUL, 145 p.

IUCN. (2010). IUCN Red List of Threatened Species. Available at http://www.iucnredlist.org/ (last accessed 15 august 2011).

Johnson, W. E., Onorato, D. P., Roelke, M. E., Land, E. D., Cunningham, M., et al. (2010) Genetic restoration of the Florida panther. Science, 329, 1641-1645.

Kumla, S., Doolgindachbaporn, S., Sudmoon, R. \& Sattayasai, N. (2012). Genetic variation, population structure and identification of yellow catfish, Mystus nemurus $(\mathrm{C} \& \mathrm{~V})$ in Thailand using RAPD, ISSR and SCAR marker. Mol Biol Rep, 39, 52015210. doi: 10.1007/s11033-011-1317-x.

Lecomte, F., Grant, W. S., Dodson, J. J., Rodriguez-Sanchez, R. \& Bowen, B. W. (2004). Living with uncertainty: genetic imprints of climate shifts in East Pacific anchovy (Engraulis mordax) and sardine (Sardinops sagax). Mol Ecol, 13, 21692182.

Lessios, H. A \& Robertson, D. R. (2006). Crossing the impassable: genetic connections in 20 reef fishes across the eastern Pacific barrier. Proc R Soc B, 273, 2201-2208.

Mazzer, A. M. \& Gonçalves, M. L. (2011). Aspectos geomorfológicos da baía da babitonga, Santa Catarina, Brasil: caracterização morfométrica. Rev Bras Geomor, $12,115-120$. 
Moller Jr., O. O., Piola, A. R., Freitas, A. C. \& Campos, E. J. D. (2008). The effects of river discharge and seasonal winds on the shelf off southeastern South America. Cont Shelf Res, 28, 1607-1624.

Moritz, C. (2002). Strategies to protect biological diversity and the evolutionary processes that sustain it. Syst Biol, 51, 238-254.

Nelson, M. F., Anderson, N. O. (2013) How many marker loci are necessary? Analysis of dominant marker data sets using two popular population genetic algorithms. Ecol Evol, 3, 3455-3470.

Pampoulie, C., Gysels, E. S., Maes, G. E., Hellemans, B., Leentjes, V., Jones, A. G. \& Volckaert, F. A. M. (2004). Evidence for fine-scale genetic structure and estuarine colonisation in a potential high gene flow marine goby (Pomatoschistus minutus). Heredity, 92, 434-445.

Patarnello, T., Volckaert, F. A. M. J. \& Castilho, R. (2007). Pillars of Hercules: is the Atlantic-Mediterranean transition a phylogeographical break? Mol Ecol, 16, 44264444

Pritchard, J. K., Stephens, M. \& Donnelly, P. (2000). Inference of population structure using multilocus genotype data. Genet, 155, 945-959.

Reddy, P., Sarla, N. \& Siddiq, E. A. (2002). Inter simple sequence repeat (ISSR) polymorphism and its application in plant breeding. Euphytica, 128, 9-17.

Robins, C. R., Ray, G. C., Peterson, R. T. \& Douglass, J. (1986). A field guide to Atlantic coast fishes of North America. Houghton Mifflin, Boston, MA

Sadovy, Y. \& Eklund, A. (1999). Synopsis of Biological Data on the Nassau Grouper, Ephinephelus striatus, and the Jewfish, E. itajara. NOAA Tech Rep NMFS, 65p.

Saitou, N. \& Nei, M. (1987). The Neighbor-joining method: a new method for reconstructing phylogenetic trees. Mol Biol Evol, 4, 406-425. 
Sambrook, J. \& Russel, D. W. (2001). Molecular Cloning: A Laboratory Manual. 3.ed. New York: Cold Spring Harbor Laboratory. New York.

Seyoum, S., Tringali, M. D., Barthel, B. L., Puchulutegui, C., Davis, M. C., Collins, A. B., Craig, M. T. (2013). Isolation and characterization of 29 polymorphic microsatellite markers for the endangered Atlantic goliath grouper (Epinephelus itajara), and the Pacific goliath grouper (E. quinquefasciatus). Conserv Genet Res, 5, 729-732.

Silva-Oliveira, G. C., Rêgo, P. S., Schneider, H., Sampaio, I \& Vallinoto, M. (2008). Genetic characterisation of populations of the critically endangered Goliath grouper (Epinephelus itajara, Serranidae) from the Northern Brazilian coast through analyses of mtDNA. Genet Mol Biol, 31, 988-994.

Slatkin, M. (1993). Isolation by distance in equilibrium and nonequilibrium populations. Evolution, 47, 264-279

Smith, C. L. (1971). A revision of the American groupers: Epinephelus and allied genera. Am Mus Nat Hist, 146, 69-241.

Schunter, C., Carreras-Carbonell, J., Planes, S., Sala, E., Ballesteros, E., et al. (2011). Genetic connectivity patterns in an endangered species: The dusky grouper (Epinephelus marginatus). J Exp Mar Biol Ecol, 401, 126-133. doi:10.1016/j.jembe.2011.01.021

Swofford, D. L. (2000). PAUP*. Phylogenetic analysis using parsimony (*and other methods). Vers. 4. Sinauer, Sunderland, MA.

Telles, M. P. C., Monteiro, M. S. R, Rodrigues, F. M., Soares T. N., Resende, L. V., et al. (2001). Marcadores RAPD na análise de divergência genética entre raças de bovinos e número de locos necessários para a estabilidade da divergência estimada. Cienc Anim Bras, 2, 87-95. 
Wei, L., Wen-Xiu, S., Jun, F. \& Chao-Chao, Z. (2013). Genetic diversity of wild and cultured swamp eel (Monopterus albus) populations from central China revealed by ISSR markers. Biologia, 68, 727-732.

Wikramanayake, E., Dinerstein, E., Seidensticker, J. Lumpkin, S., Pandav, B., Shrestha, M., et al. (2011). A landscape-based conservation strategy to double the wild tiger population. Conserv Lett, 4, 219-227

Williams, L. M. \& Oleksiak, M. F. (2008). Signatures of selection in natural populations adapted to chronic pollution. BMC Evol Biol, 8, 282.

Wolfe, A. D. (2005). ISSR techniques for evolutionary biology. Method Enzymol, 395, 134-144.

Wright, S. (1951). The genetical structure of populations. Ann Eugen, 15, 313-354.

Yeh, F. C., Boyle, T. Y. Z. \& Xiyan, J. M. (1999). POPGENE (v. 131): microsoft window based freeware for population genetic analysis. Alberta: University of Alberta and Center for International Forestry Research, 29p. 
Tables.

Table 1. Number of specimens of Epinephelus itajara obtained from each locality along the Atlantic coast of South America.

\begin{tabular}{ccc}
\hline Locality & Acronym & $\mathrm{N}$ \\
\hline French Guiana & FG & 17 \\
Pará & PA & 17 \\
Piauí & PI & 12 \\
Ceará & CE & 1 \\
Rio Grande do Norte & RN & 8 \\
Pernambuco & PE & 11 \\
Bahia & BA & 15 \\
São Paulo & SP & 2 \\
Paraná & PR & 1 \\
Santa Catarina & SC & 11 \\
& & $\mathrm{~N}=93$ \\
\hline
\end{tabular}

Table 2. The ISSR primers tested, their sequences and annealing temperatures. The primers in bold type were those used in the present study.

\begin{tabular}{ccc}
\hline Primer & $5^{\prime}-3^{\prime}$ sequence & Annealing temperature $\left({ }^{\circ} \mathrm{C}\right)$ \\
\hline ISSR 1 & $(\mathrm{AG}) 8 \mathrm{~T}$ & 50.4 \\
ISSR 2 & $(\mathrm{AG}) 8 \mathrm{C}$ & 52.8 \\
ISSR 3 & $(\mathrm{GA}) 8 \mathrm{~T}$ & 50.4 \\
ISSR 4 & $(\mathrm{GA}) 8 \mathrm{C}$ & 52.8 \\
ISSR 5 & $(\mathrm{CT}) 8 \mathrm{G}$ & 52.0 \\
ISSR 6 & $(\mathrm{AG}) 8 \mathrm{YC}$ & 52.8 \\
ISSR 7 & $(\mathrm{AG}) 8 \mathrm{YA}$ & 54.0 \\
ISSR 8 & $(\mathrm{GA}) 8 \mathrm{YT}$ & 52.8 \\
ISSR 9 & $(\mathrm{GA}) 8 \mathrm{YC}$ & 52.8 \\
ISSR 10 & $(\mathrm{GA}) 8 \mathrm{YG}$ & 54.0 \\
ISSR 11 & $(\mathrm{CT}) 8 \mathrm{RA}$ & 50.0 \\
ISSR 12 & $(\mathrm{AC}) 8 \mathrm{YG}$ & 54.0 \\
ISSR 13 & $(\mathrm{GGAC}) 3^{\mathrm{a}}$ & 51.0 \\
ISSR 14 & $(\mathrm{GGAC}) 3 \mathrm{C}$ & 51.0 \\
ISSR 15 & $(\mathrm{GGAC}) 3 \mathrm{~T}$ & 51.0 \\
ISSR 16 & $(\mathrm{AACC}) 4$ & 51.0 \\
ISSR 17 & $(\mathrm{GGAC}) 4$ & 51.0 \\
\hline
\end{tabular}


Table 3. Polymorphism observed in E. itajara within each locality, in relation to the global set of loci.

\begin{tabular}{ccccc}
\hline Locality & $\begin{array}{c}\text { Number of } \\
\text { specimens }\end{array}$ & $\begin{array}{c}\text { Total number of } \\
\text { loci }\end{array}$ & $\begin{array}{c}\text { Number of } \\
\text { variable loci }\end{array}$ & $\begin{array}{c}\text { Percentage of } \\
\text { polymorphic } \\
\text { loci (\%) }\end{array}$ \\
\hline French Guiana & 17 & 94 & 34 & 36.2 \\
Pará & 17 & 94 & 32 & 34.0 \\
Piauí & 12 & 94 & 23 & 24.5 \\
Ceará & 1 & 94 & 0 & 0.0 \\
Rio Grande do Norte & 8 & 94 & 25 & 26.6 \\
Pernambuco & 11 & 94 & 27 & 28.7 \\
Bahia & 15 & 94 & 45 & 47.9 \\
São Paulo & 2 & 94 & 0 & 0.0 \\
Paraná & 1 & 94 & 0 & 0.0 \\
Santa Catarina & 11 & 94 & 75 & 79.8 \\
\hline
\end{tabular}

Table 4. Polymorphism observed in E. itajara within each locality, in relation to the global set of loci recorded at each site.

\begin{tabular}{ccccc}
\hline Locality & $\begin{array}{c}\text { Number of } \\
\text { specimens }\end{array}$ & $\begin{array}{c}\text { Total number of loci } \\
\text { at locality }\end{array}$ & $\begin{array}{c}\text { Number of } \\
\text { variable loci }\end{array}$ & $\begin{array}{c}\text { Percentage of } \\
\text { polymorphic loci } \\
(\%)\end{array}$ \\
\hline French Guiana & 17 & 81 & 36 & 44.4 \\
Pará & 17 & 78 & 34 & 43.6 \\
Piauí & 12 & 76 & 28 & 36.8 \\
Ceará & 1 & 58 & 0 & 0.0 \\
Rio Grande do Norte & 8 & 70 & 23 & 32.9 \\
Pernambuco & 11 & 79 & 29 & 36.7 \\
Bahia & 15 & 82 & 43 & 52.4 \\
São Paulo & 2 & 64 & 0 & 0.0 \\
Paraná & 1 & 72 & 0 & 0.0 \\
Santa Catarina & 11 & 78 & 74 & 94.9 \\
\hline
\end{tabular}


Table 5. Nei's (1973) genetic diversity (h) and Shannon's Information index (I) for the populations of Epinephelus itajara. $\mathrm{SC}=$ population from Santa Catarina state, Southern Brazil.

\begin{tabular}{lcc}
\hline Populations & h & I \\
\hline SC & 0.1457 & 0.2273 \\
All -SC & 0.1314 & 0.1996 \\
All & 0.1628 & 0.2545 \\
\hline
\end{tabular}

Table 6. Population genetic parameters of Epinephelus itajara.

\begin{tabular}{ll}
\hline Parameters & Values \\
\hline Total diversity (Ht) & $0.2119 \pm 0.0434$ \\
Diversity within populations (Hs) & $0.1385 \pm 0.0196$ \\
Global genetic diferentiation $\left(\mathrm{G}_{\mathrm{ST}}\right)$ & 0.3463 \\
Gene Flow (Nm) & 0.9436 \\
Percentage of polymorphic loci & 58.06 \\
\hline
\end{tabular}

Table 7. Pairwise $\mathrm{G}_{\mathrm{ST}}$ for the comparisons among the Epinephelus itajara populations sampled in the present study (acronyms as in Table 1).

\begin{tabular}{cccccccc}
\hline & FG & PA & PI & RN & PE & BA & SC \\
\hline SC & 0.590 & 0.571 & 0.480 & 0.481 & 0.476 & 0.733 & - \\
\hline
\end{tabular}


Table 8. Overall AMOVA results for the populations of Epinephelus itajara from the Atlantic coast of South America. $(\mathrm{p}<0.01)$.

\begin{tabular}{ccccc}
\hline $\begin{array}{c}\text { Source of } \\
\text { variation }\end{array}$ & $\begin{array}{c}\text { Degrees } \\
\text { of } \\
\text { freedom }\end{array}$ & Sum of squares & $\begin{array}{c}\text { Components of } \\
\text { the variance }\end{array}$ & $\begin{array}{c}\text { Percentage of variation } \\
(\%)\end{array}$ \\
\hline Between samples & 9 & 540.762 & $5.70936 \mathrm{Va}$ & 42.7 \\
Within samples & 86 & 658.447 & $7.65636 \mathrm{Vb}$ & 57.2 \\
\hline Total & 95 & 1199.208 & 13.36571 & \\
\hline$\Phi_{\mathrm{ST}} 0.42716$ & & & & \\
\hline
\end{tabular}

Table 9. AMOVA results for the Epinephelus itajara populations divided into two groups: group 1: FG, PA, PI, CE, RN, PE, BA, SP, PR; group 2: SC (acronyms as in Table 1). (p < $0.01)$.

\begin{tabular}{ccccc}
\hline Source of variation & $\begin{array}{c}\text { Degrees of } \\
\text { freedom }\end{array}$ & Sum of squares & $\begin{array}{c}\text { Components of the } \\
\text { variance }\end{array}$ & $\begin{array}{c}\text { Percentage of } \\
\text { variation (\%) }\end{array}$ \\
\hline $\begin{array}{c}\text { Among groups } \\
\text { Among }\end{array}$ & 1 & 219.397 & $8.75411 \mathrm{Va}$ & 43.6 \\
$\begin{array}{c}\text { populations within } \\
\text { groups }\end{array}$ & 8 & 321.365 & $3.64606 \mathrm{Vb}$ & 18.1 \\
$\begin{array}{c}\text { Within populations } \\
\text { Total }\end{array}$ & 86 & 658.447 & $7.65636 \mathrm{Vc}$ & 38.1 \\
\hline & 95 & 1199.208 & 20.05653 & \\
\hline & $\Phi_{\mathrm{SC}}$ & 0.32259 & & \\
& $\Phi_{\mathrm{ST}}$ & 0.61826 & & \\
& $\Phi_{\mathrm{CT}}$ & 0.43647 & & \\
\hline
\end{tabular}


Figure captions.

Fig. 1. Map showing the sampling localities (black dots) for Epinephelus itajara along the Atlantic coast of South America (for acronyms, see Table 1). The credits for the fish illustration must be attributed to Dianne Rome Peebles, (C) 1992.

Fig. 2. ISSR profiles (primer ISSR 15) as a way to show the genetic profiles of the Santa Catarina population and the other accessed populations (for acronyms, see Table I).

Fig. 3. Multi-dimensional scaling plot of the genetic similarities (simple matching index) observed among the studied E. itajara specimens.

Fig. 4. Maximum parsimony topology. Numbers above and below the branches indicate bootstrap and jackknife support, respectively. The specimen numbers are preceded by the acronym representing their source locality (see Table I).

Fig. 5. Linear regression between genetic distances and geographical distances $(\mathrm{km})$ for Epinephelus itajara in the Atlantic coast South America

Fig. 6. Pattern of genetic cohesiveness/distinctiveness observed in Epinephelus itajara by the bayesian structuring analysis $(\mathrm{K}=2)$. Each vertical line represents one individual. The length of each line reflects the probability of each individual's membership to each cluster (for acronyms, see Table I). 
Fig. 7. Averaged sea surface temperature $(1 \mathrm{~km})$ for August, from the Group of High Resolution Sea Surface Temperature (GRHSST, http://podaac.jpl.nasa.gov). 
Figure 1.

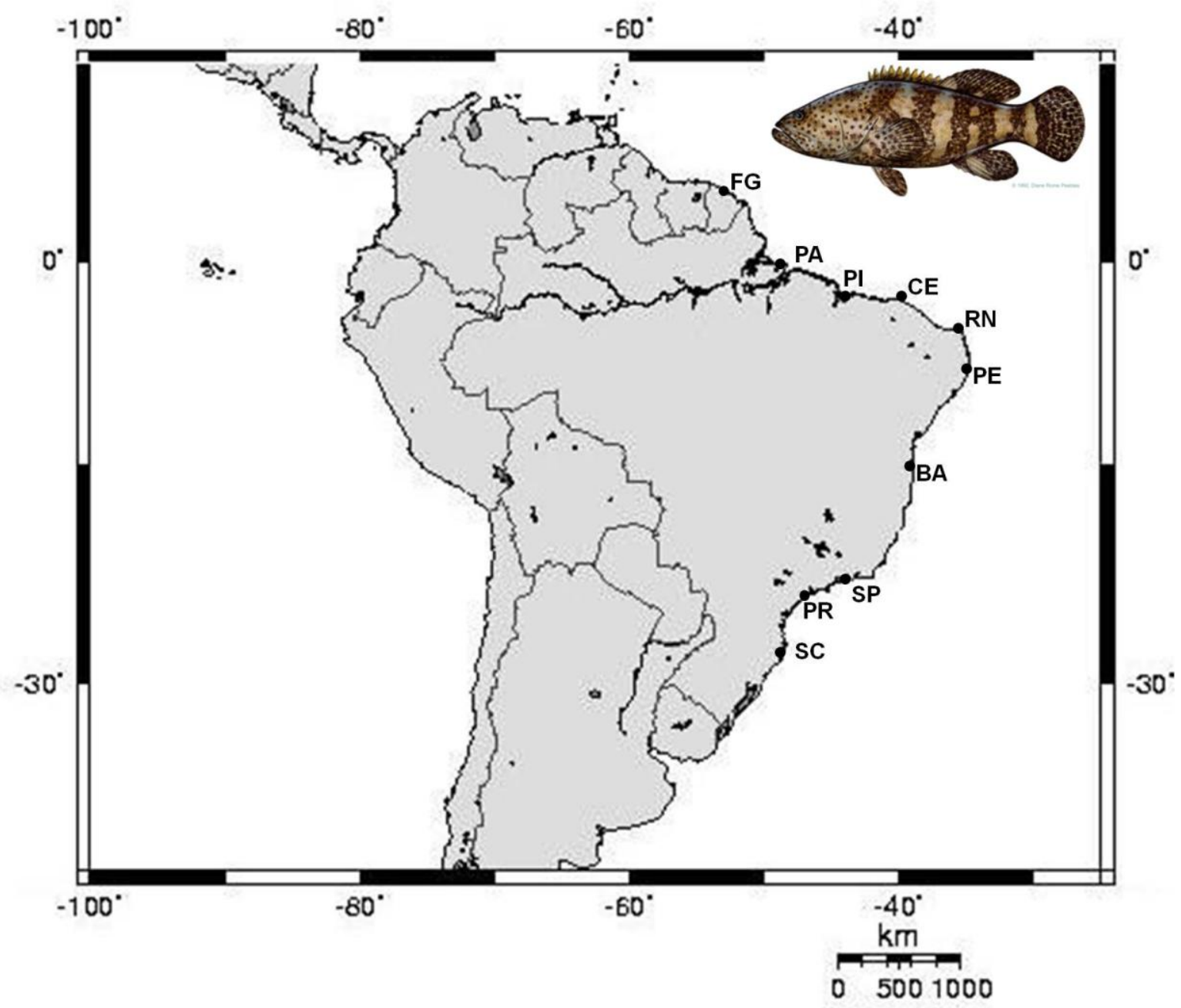


Benevides et al. Goliath grouper DNA figure2

Figure 2.

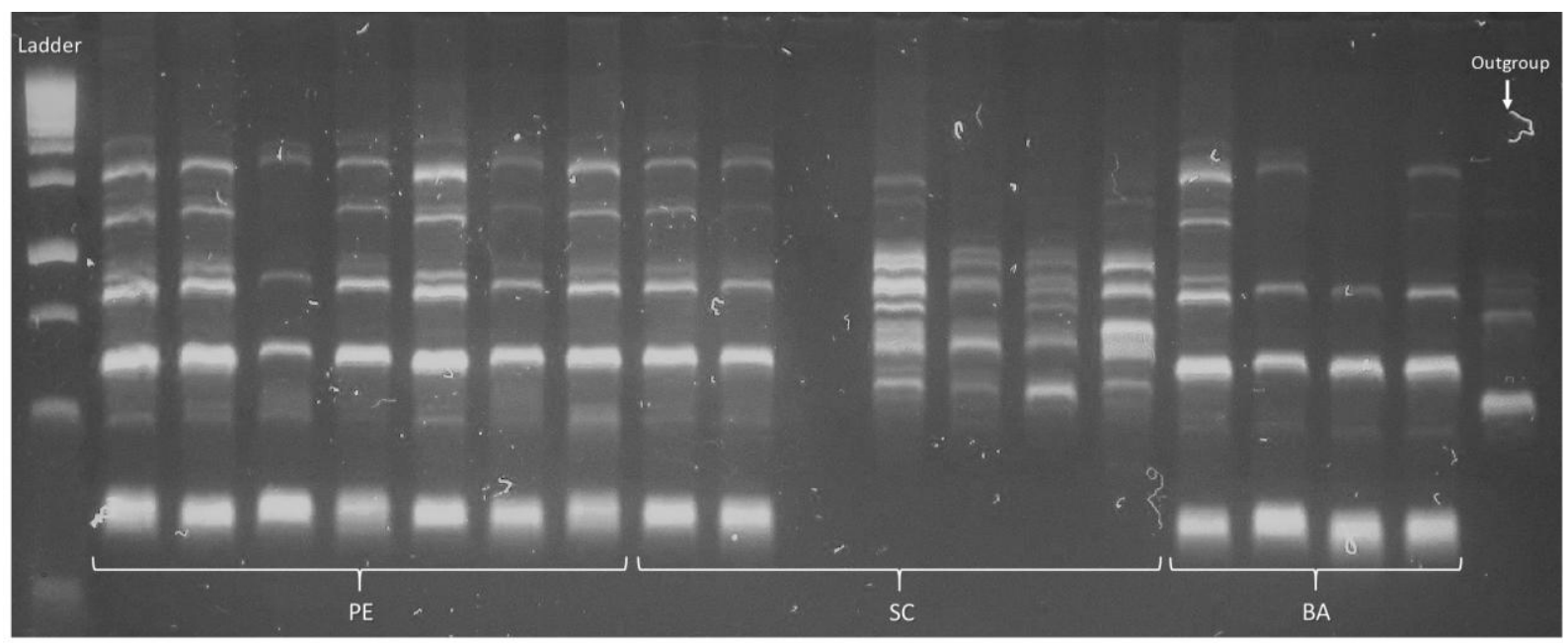


Benevides et al. Goliath grouper DNA figure3

Figure 3.

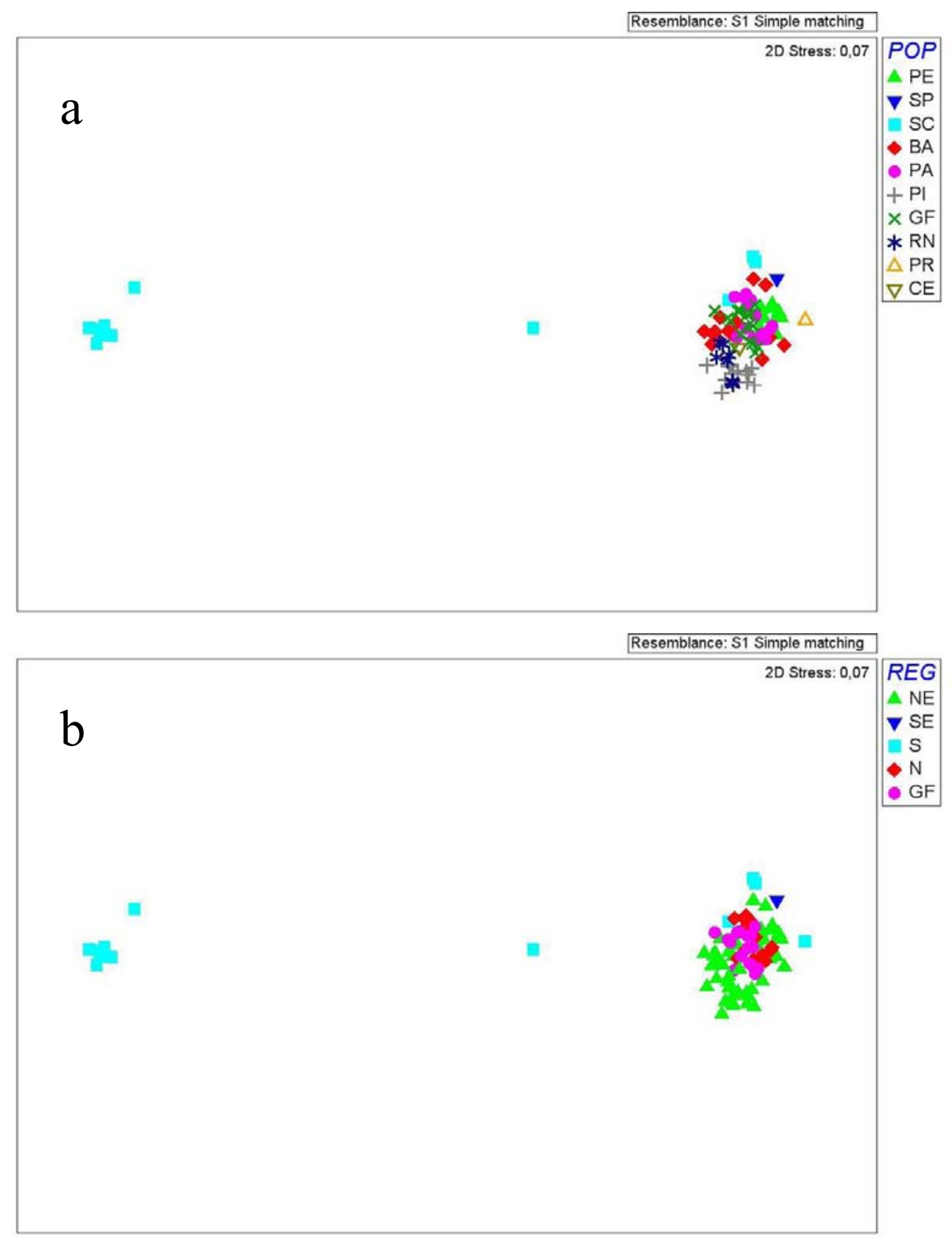


Benevides et al. Goliath grouper DNA figure4

Figure 4.

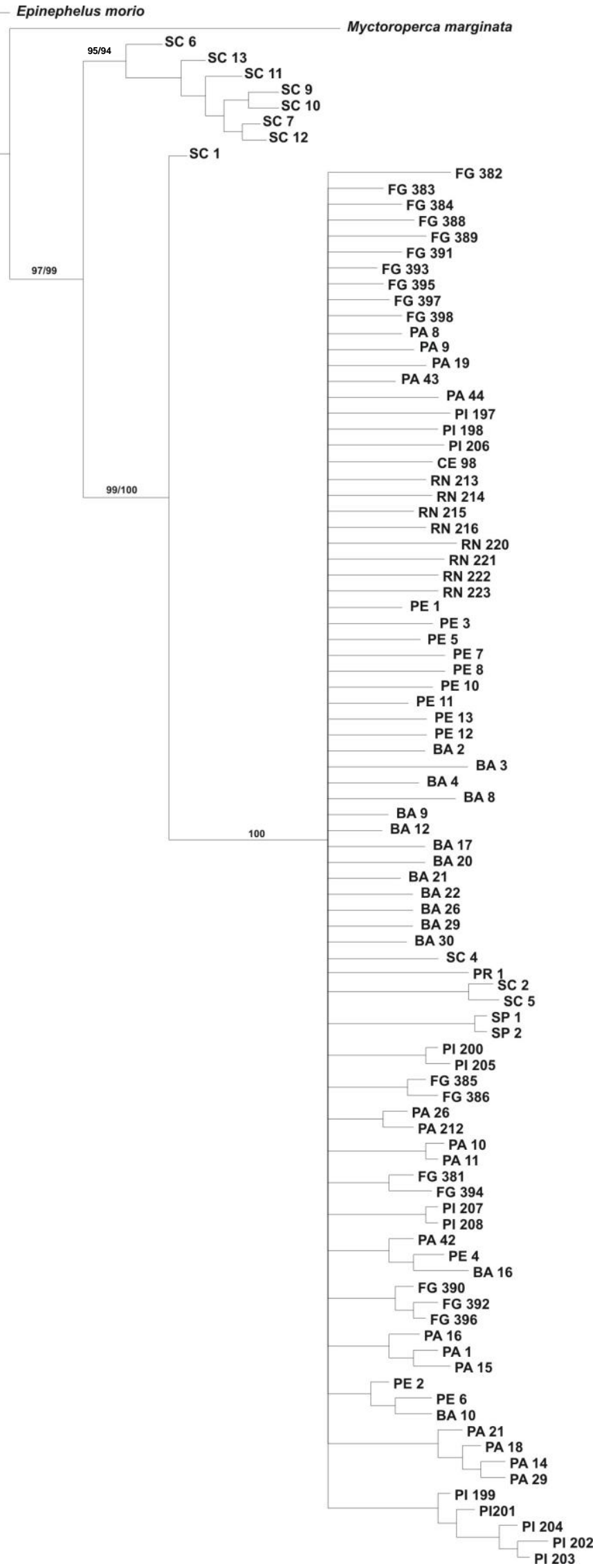


Figure 4.

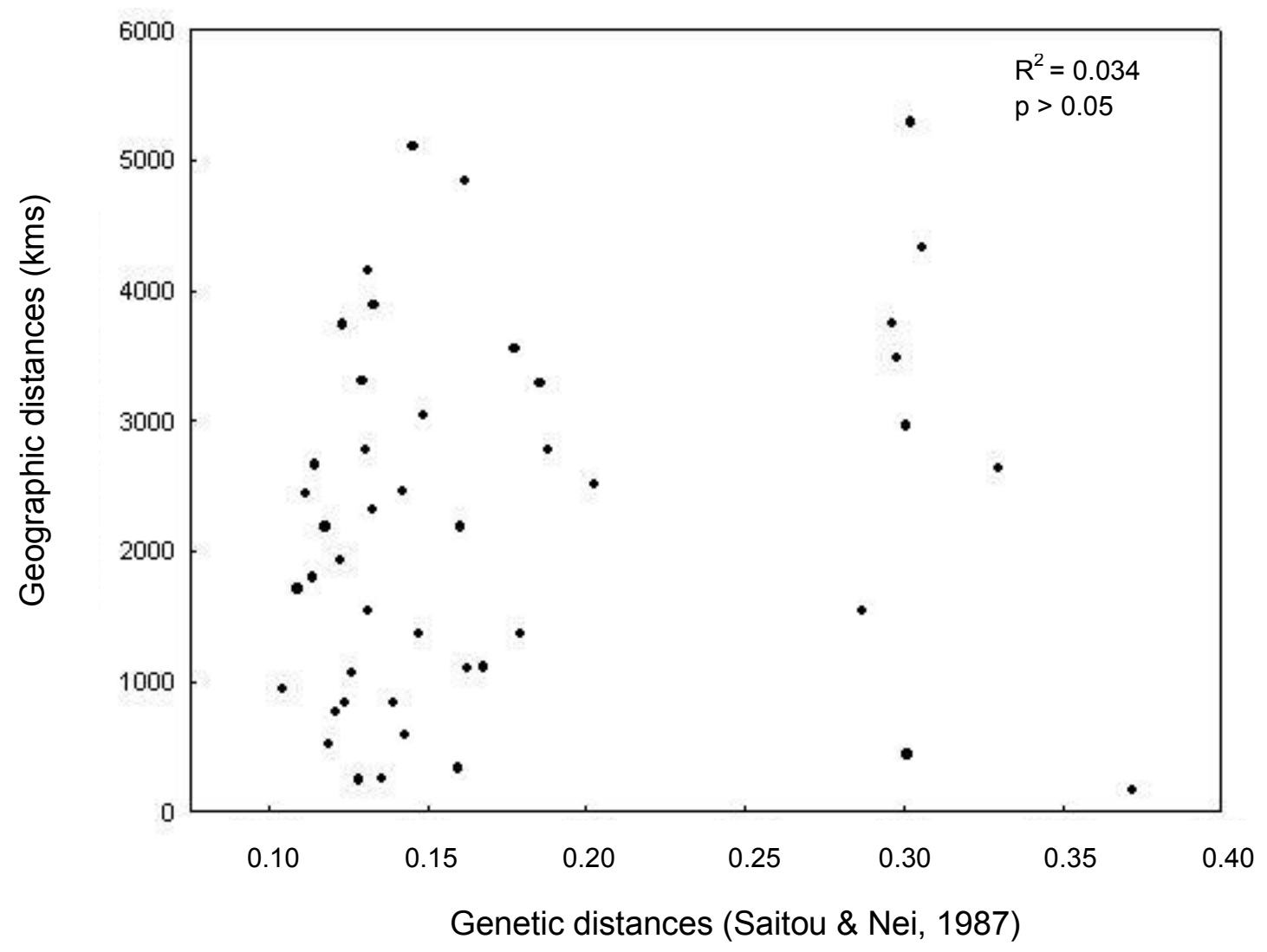


Benevides et al. Goliath grouper DNA figure6

Figure 5.

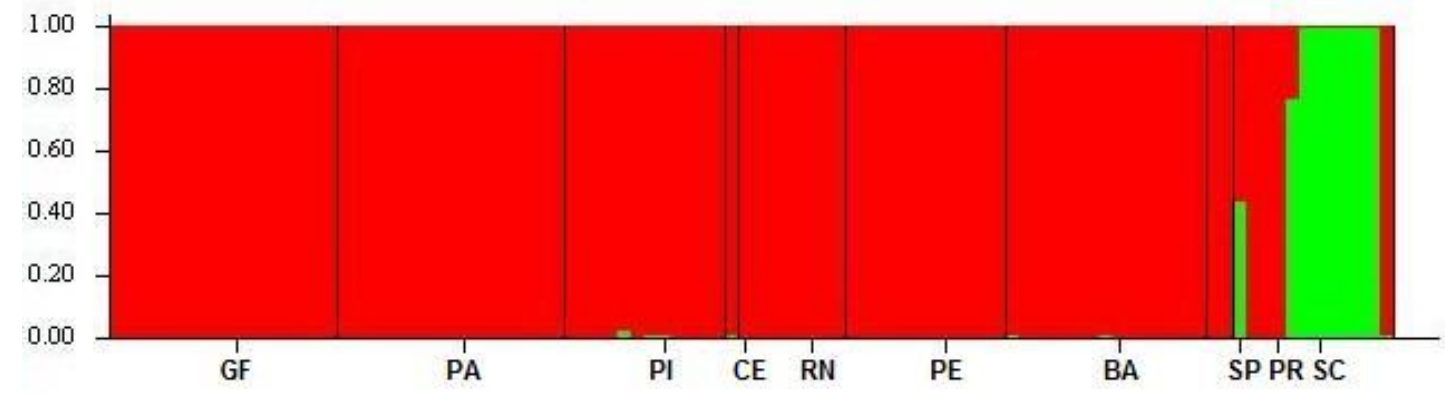


Benevides et al. Goliath grouper DNA figure7

Figure 7.

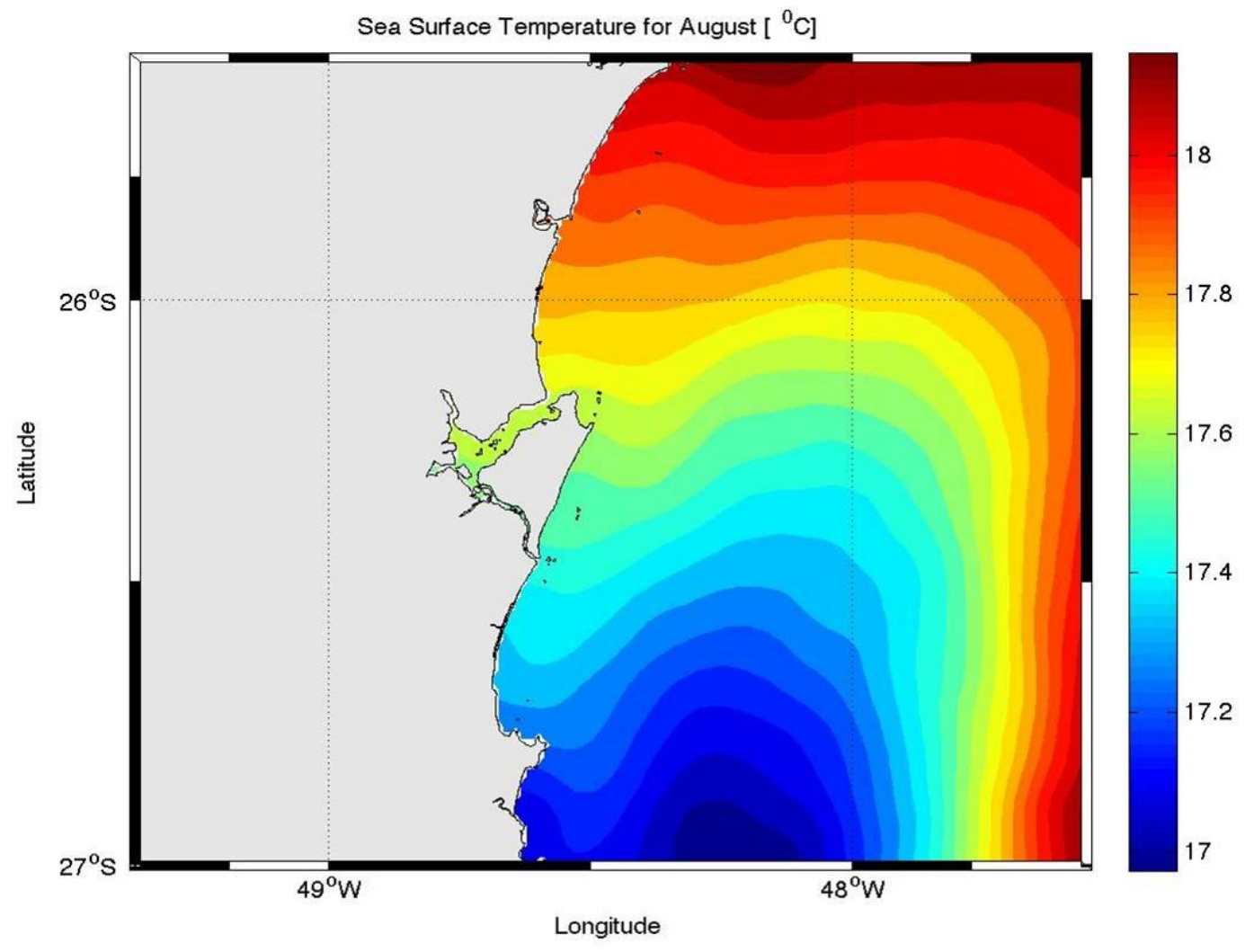

